ACTA UNIVERSITATIS LODZIENSIS

FOLIA LITTERARIA POLONICA 4(42) 2017

http://dx.doi.org/10.18778/1505-9057.42.09

Barbara Czarnecka*

\title{
Włosy w kobiecych narracjach lagrowych
}

Czy czujecie ten moment strzyżenia włosów kobiety? Owo „osadzenie na tronie” żydowskich oblubienic przed ich czarnym weselem! Sam diabel trzymał do tej ceremonii czarne świece! Blask ich płomyków zastygł w martwo-zielonych oczach owego „fryzjera”. Czytałam w monografii Stefana Zweiga, jak rankiem, przed wyprowadzeniem na szafot, obcięto w celi włosy Marii Antoninie. Gdzieś indziej czytałam o skazanych na śmierć, którym w jednej chwili siwiały włosy, w momencie gdy nożyce kata zbliżały się do szyi przy ścinaniu włosów przed egzekucją. W Treblince i w innych miejscach było żydowskich Marii Antonim setki, tysiące. Od szóstego roku życia, od pierwszych warkoczyków ${ }^{1}$.

Włosami więźniów w obozach koncentracyjnych i zagłady dysponowało SS i Główny Urząd Gospodarczo-Administracyjny III Rzeszy. W drugim tomie kanonicznej pracy Auschwitz 1940-1945. Węzłowe zagadnienia z dziejów obozu ${ }^{2}$, w rozdziale Utylizacja zwłok ofiar (podrozdział Wykorzystanie włosów ofiar) znajdziemy historyczne informacje dotyczące włosów obciętych więźniom osadzonym w obozie i włosów kobiet żydowskich, ofiar zagłady bezpośredniej. Praca mówi o higienicznych i prewencyjnych (utrudnienie ucieczki) ${ }^{3}$ powodach pozbawiania owłosienia więźniów oraz o zastosowaniu włosów ofiar jako surowca przemysłowego ${ }^{4}$.

* Dr hab.; Uniwersytet Jagielloński, Wydział Polonistyki, Katedra Historii Literatury Polskiej XX wieku; ul. Gołębia 16-18,30-007 Kraków; barbara.czarnecka@uj.edu.pl.

${ }^{1}$ R. Auerbach, Treblinka. Reportaż, oprac. M. Polit, przeł. K. Szymaniak, „Zagłada Żydów. Studia i Materiały", t. 8 (2013), s. 56.

${ }^{2}$ Auschwitz 1940-1945. Węzłowe zagadnienia z dziejów obozu, red. W. Długoborski, F. Piper, Wydawnictwo Państwowego Muzeum Oświęcim-Brzezinka, Oświęcim 1995, t. 2.

${ }^{3}$ Wiesław Kielar tak relacjonował przygotowania do ucieczki z Auschwitz latem 1944 roku: „Przestaliśmy strzyc sobie włosy. Nie rzucało się to specjalnie nikomu w oczy, tym bardziej, że już wielu starych więźniów miało zezwolenie na noszenie długich włosów. Jedynie Kazek Gosk podejrzliwie patrzył na nasze podrastające jeżyki, ale nic nie mówił”, W. Kielar, Anus mundi, Wydawnictwo Literackie, Kraków 1980, s. 322.

${ }^{4}$ Auschwitz 1940-1945..., t. 2, s. 299-300. 
Warto przypomnieć kilka podstawowych faktów. W sierpniu 1942 roku WVHA (Główny Urząd Gospodarczo-Administracyjny) wydał zarządzenie skierowane do komendantury Auschwitz i innych obozów o systematycznym gromadzeniu obcinanych włosów minimum $2 \mathrm{~cm}$ długości. Istniały też plany stworzenia przemysłu przerobu włosów na miejscu, jednak w styczniu 1943 roku komendantom 11 obozów polecono przekazywanie surowca, w cenie 50 fenigów za 1 kg włosów, zewnętrznym firmom przemysłowym. Na Majdanku już w 1942 roku zgromadzono ponad $160 \mathrm{~kg}$ włosów, a od lutego 1943 do marca 1944 sprzedano stamtąd 730 kg włosów. Nie znamy analogicznych danych dla Auschwitz, ale po wyzwoleniu obozu znaleziono tam ok. $7000 \mathrm{~kg}$ włosów pochodzących od ok. 140000 zgładzonych osób5.

Zarysowana wyżej historyczna faktografia nie traktuje o włosach jako szczątkach ludzkich. Temat ten podejmuje refleksja o charakterze muzealniczym, związana z konserwacją i ekspozycją włosów ofiar oraz z, równie ważnym, etycznym wymiarem tego reliktu'.

Mnie zaś tutaj interesują zagadnienia związane z włosami, które zostały ukazane przede wszystkim w kobiecych narracjach lagrowych, choć odwołam się też do narracji męskiej oraz doświadczenia obozu dla wysiedlonych, stalagu i oflagu oraz obozu zagłady. Kryterium wyboru autorek stanowić będzie ich osobiste doświadczenie obozowe. Jak się okazuje, spośród wielu dramatycznych doznań, $\mathrm{w}$ jakie obfitowało osadzenie w lagrze, pamięć kobiet nader często wybierała te związane z ciałem. Spośród utrwalonych wspomnień wyróżniają się przeżycia powiązane $z$ włosami i łatwo zauważyć, że są one intensywne, głębokie, ostre. Znajdują się na pograniczu intymności albo już po jej stronie. Każde z nich związane jest z innym obrazem obozu, innym losem. Mogą one zatem stanowić rodzaj kategorii interpretacyjnej, odsłaniającej warstwy obozowej egzystencji. Dokonuję tutaj zaledwie fragmentarycznego ich przeglądu i prezentacji jedynie wyboru możliwych doświadczeń. Nie szukam dla nich metafor i uogólniających figur, ale próbuję uchwycić skalę przeżyć i w jej rozpiętości indywidualne głosy pamięci.

Włosy jako surowiec przemysłowy pozyskiwano nie tylko z ciał zagazowanych ofiar. Więzień kilku obozów koncentracyjnych, Michał Piotrowski, tak po latach wspominał pewne coniedzielne, a jednak wyjątkowe postrzyżyny w męskim sektorze Ravensbrück (opisywaną sytuację można prawdopodobnie datować na 1942 rok):

Zaczęło się strzyżenie włosów. [...] Fryzjer tępą maszynką zrobił bruzdę od czoła do tyłu głowy i grzecznie powiedział, że już po wszystkim. [...] Wkrótce i nam zrzedły

\footnotetext{
5 Tamże.

${ }^{6}$ Interesującego materiału do dyskusji na ten temat dostarcza Marta Zawodna w artykule Wokót tego, co pozostało. Biograficzne podejście do badań nad szczątkami ludzkimi na przykładzie włosów eksponowanych w Muzeum Auschwitz-Birkenau, „Kultura i Społeczeństwo” 2007, nr 2.
} 
miny, gdy dowiedzieliśmy się, że co kilka tygodni będziemy strzyżeni w podobny sposób. Podobno nie wolno marnować surowca przydatnego do robót tapicerskich i dlatego więźniów będzie się strzyc rzadziej, a włosy zbierać do specjalnych worków. Dłuższe włosy mogłyby jednak ułatwiać więźniom ucieczkę, toteż komendant obozu Suhren kazał wystrzygać więźniom co dwa tygodnie przez środek głowy bruzdy. Strzyżenie „na pałę” miało odbywać się co kilka miesięcy. Bruzdy na naszych głowach przyjęły nazwę Suhrenstrasse (ulica Suhrena) ${ }^{7}$.

Więźniowie innych obozów nazywali pas wyciętych albo wygolonych przez środek głowy włosów „Lagerstrasse dla wszy” lub ,ścieżką dla wszy”.

W podobny sposób traktowano kobiety. Wspomina o tym Żydówka Maria Puretz w powojennej relacji o osadzeniu w Gundelsdorfie, podobozie Flossenbürg, we wrześniu 1944 roku: „Za kradzież kilku ziemniaków nie tylko bito, ale golono przez środek głowy włosy". Semickość narratorki i czas wydarzeń wskazują na to, że nie golono całej głowy, zakładając przyszłe wykorzystanie włosów jako surowca do pobrania ze zwłok.

Nie w każdym obozie od początku jego istnienia i nie wszystkim przybywającym więźniom golono głowy, szczególnie jeśli miało to miejsce przed wojną. Wolfgang Sofsky pisze o pierwszych dniach Dachau (marzec 1933): „Jednolitych ubiorów więźniarskich nie ma. Wszystko przebiega w porządku, bez krzyków i maltretowania. Nikomu nie przychodzi do głowy, żeby nowo przybyłym obcinać włosy"10. Brak tej procedury mógł, również w czasie trwania wojny, oznaczać fazę wczesnej organizacji obozu. Danuta Brzosko-Mędryk o okolicznościach przybycia do obozu KL Lublin transportu ,,pawiaczek” powie: „W styczniu 1943 roku Niemcy nie byli przygotowani na przyjęcie kobiet-więźniów

\footnotetext{
${ }^{7}$ M. Piotrowski, Nie tylko w Ravensbrück ...1723 dni za drutami KL Auschwitz, Neuengamme, Ravensbrück, Berlin-Lichterfelde, Prószyński i S-ka, Warszawa 1991, s. 72-73.

${ }^{8}$ Stanisław Grzesiuk tak to relacjonował: „Pozwolono już zapuścić włosy. Już nie golono nam głów brzytwą każdego tygodnia. Strzyżono maszynką raz na trzy miesiące, a każdego tygodnia golono tylko czterocentymetrową ścieżkę, która biegła od czoła do tylu przez środek głowy. Żeby każdy był znaczony, gdyby chciał uciekać. «Władze» robiły sobie wąskie, dwucentymetrowe ścieżki, a nam golono szerokie, jak szosa. Ścieżki te nazywaliśmy «ulica dla wszy». Włosy były Niemcom potrzebne do jakichś celów. Gdy raz na trzy miesiące strzyżono nas, włosy zabierano w pudła i każdy blok oddawał esesmanowi wszystko co zebrał", S. Grzesiuk, Pięć lat kacetu, Książka i Wiedza, Warszawa 1985, s. 261. Portret tak wygolonego więźnia można zobaczyć np. w albumie opracowanym przez Janinę Jaworską, Nie wszystek umrę... Twórczość plastyczna Polaków w hitlerowskich więzieniach i obozach koncentracyjnych 1939-1945, Książka i Wiedza, Warszawa 1975. Jest to wykonany ołówkiem i kredką rysunek autorstwa Kazimierza Stachiewicza Portret więźnia powstały w Gusen w 1943 roku (rycina 413).

${ }^{9}$ Dokumenty zbrodni i męczeństwa, red. M. Borwicz, N. Rost, J. Wulf, Centralny Komitet Żydów Polskich. Wojewódzka Żydowska Komisja Historyczna, Kraków 1945, s. 55.

${ }^{10}$ W. Sofsky, Ustrój terroru. Obóz koncentracyjny, przekł. M. Łukasiewicz, Żydowski Instytut Historyczny im. Emanuela Ringelbluma, Warszawa 2016, s. 9.
} 
politycznych. Wprowadzono nas do obozu bez stosowanego gdzie indziej reżimu: wstępna kąpiel, tatuaż, pasiaki, strzyżenie włosów. I właśnie dzięki temu uniknęłyśmy psychicznego sparaliżowania" ".1. Według autorki Matyldy etap prowizorium, z którego Majdanek nigdy do końca nie wyszedł, polegający na brakach w organizacji i wybitnie prymitywnych warunkach obozu, pozwalał uniknąć szoku instrumentalnego „rytuału przyjęcia”. Ale brak golenia mógł oznaczać też niewydolność fryzjerów wobec nawału pracy związanej z napływem żydowskich transportów. W opracowaniu historycznym pod redakcją Tadeusza Mencla przeczytamy, że ,na Majdanku nie strzyżono więźniarek, tak jak w innych obozach" ${ }^{2}$. Trudno powiedzieć, czy jest tutaj mowa o więźniarkach wszystkich narodowości, czy jedynie o kobietach pochodzenia nieżydowskiego. Wszak, jak podaje Andrzej Strzelecki, Główny Urząd Gospodarczo-Administracyjny Rzeszy potwierdził w lipcu 1943 roku przyjęcie z obozu Auschwitz i Majdanka $3000 \mathrm{~kg}$ kobiecych włosów ${ }^{13}$.

W stosunku do więźniarek lagrów kluczowe znaczenie miały procedury pierwszego obozu koncentracyjnego dla kobiet, jakim był działający od 1937 Lichtenburg, oraz funkcjonującego od 1939 KL Ravensbrück. Ten drugi był modelowym obozem i jego regulaminowe praktyki postępowania wobec osadzonych, oraz częściowo personel, zostały przeniesione do większości później powstających podobozów kobiecych, jak np. Birkenau czy kobiece „pola” w KL Lublin. W obozach na terenie Rzeszy przed wojną, a potem w podbitej Europie stosowano terror o porażającym wymiarze przede wszystkim wobec mężczyzn. Odsetek więźniarek w roku 1938 wynosił 3,3\%, w szybkim tempie wzrastał i w 1939 roku wynosił już 11,7\% ${ }^{14}$. Można jednak powiedzieć, że do 1942 roku kobiety znajdowały się na marginesie świata obozów koncentracyjnych, a ich los w obozach różnił się od doświadczeń męskich. Ani w centralnym zakładzie karnym dla kobiet w Moringen, ani w Lichtenburgu nie golono włosów, a kobiety zachowywały swoje prywatne ubrania. Pierwsza egzekucja kobiety odbyła się w Ravensbrück prawdopodobnie w 1941 roku, zaś w męskim sektorze tego obozu w ciągu tylko jednego miesiąca zginęło tylu mężczyzn, ile - proporcjonalnie - w obozie kobiecym w ciągu dwóch lat ${ }^{15}$. Wraz z coraz częstszym osadzaniem w obozach kobiet zaostrzały się również stosowane wobec nich restrykcje.

${ }^{11}$ D. Brzosko-Mędryk, Matylda, Wydawnictwo Ministerstwa Obrony Narodowej, Warszawa 1970, s. 26.

12 Z. Morawska, Warunki egzystencji więźniów, w: Majdanek 1941-1944, red. T. Mencel, Wydawnictwo Lubelskie, Lublin 1999, s. 137.

${ }^{13}$ A. Strzelecki, Wykorzystanie zwłok ofiar obozu, ,Zeszyty Oświęcimskie”, nr 21 (1995), s. 101.

${ }^{14}$ N. Wachsmann, Historia nazistowskich obozów koncentracyjnych, tłum. M. Antosiewicz, Świat Książki, Warszawa 2016, s. 154.

15 Tamże, s. 259. 
W Ravensbrück miejscowy personel SS ustanowił szczególnie poniżający rytuał dla kobiet przybywających do obozu, które musiały się rozbierać, iść pod prysznic i poddawać dokładnemu badaniu [ginekologicznemu - dopisek mój B.Cz.], a wielu golono również włosy na ciele. Trzeba było, ,zrezygnować z wszelkich nieśmiałych prób zachowania skromności” - napisała Buber-Neuman. Takie ataki na godność osobistą i kobiecość więźniarek [...] nie były rozpowszechnione przed wojną ${ }^{16}$.

Restrykcyjność stosowanej procedury inicjacyjnej zależała w zasadzie od lokalnej załogi SS i była ona rozmaicie, w stosunku do różnych transportów i różnych kobiet, przeprowadzana. Obrazuje to wspomnienie z Ravensbrück Marii Rutkowskiej-Kurcyuszowej: „Moje włosy ocalały spod brzytwy. Myślę, że zadecydowała o tym nie tyle ich czystość, co przypadek. Golono głowy co drugiej"17. Relacja z przybycia do tego obozu Anny Truszkowskiej-Kuliniczowej przedstawia nieco inny stan rzeczy: „Większości więźniarek ogolili głowy. Należałam do nielicznych, którym zostawili włosy"18. Austriackie badaczki podają, że w Ravensbrück golono wszystkie Rosjanki, a tylko część Francuzek i Austriaczek ${ }^{19}$. Urszula Wińska wspomina, że na wyjątkowe traktowanie mogły tam liczyć polskie sondertransporty: „Np. w 1941 r. transport specjalny z Krakowa i okolic potraktowano dodatkowym przyjęciem, goląc co dziesiątej głowę, rzekomo ze względów higienicznych. Trzy doby przebyły wszystkie w bunkrze, leżąc w celach na kamiennej posadzce. Nosiło to nazwę odwszawiania" ${ }^{20}$. W Ravensbrück (i innych obozach) golono też głowy umysłowo chorym ${ }^{21}$, nowo przyjętym na rewir i chorym na tyfus ${ }^{22}$.

W obozie kobiecym Auschwitz-Birkenau, według Amesberger, Auer i Halbmayr, tylko Żydówki golono do gołej skóry²3. Oficjalnie robiono to z przyczyn higienicznych, ale przecież uzasadnione było to również innymi względami - chodziło o upodlenie i separację od reszty obozowego społeczeństwa. Lechosław Cebo w studium Więźniarki w obozie hitlerowskim w Oświęcimiu-Brzezince podaje zaś, że do gołej skóry golono tylko te aryjki, których włosy były zaniedbane. „W większości wypadków golono owłosione miejsca na całym ciele, dezynfekując je następnie przez pocieranie jedną i tą samą brudną ścierką zamoczoną

\footnotetext{
16 Tamże.

17 M. Rutkowska-Kurcyuszowa, Kamyki Dawida. Wspomnienia, Unia, Katowice 2005, s. 147.

18 A. Truszkowska-Kuliniczowa, Mój XX wiek. Wspomnienia, Kampol, Szczecin 2004, s. 70.

${ }^{19}$ H. Amesberger, K. Auer, B. Halbmayr, Sexualisierte Gewalt. Weibliche Erfahrungen in NS-Konzentrationslagern, Mandelbaum, Wien 2004, s. 80.

${ }^{20}$ Relację Wińskiej cytuje Wanda Kiedrzyńska w monograficznym opracowaniu poświęconym kobiecemu obozowi w Ravensbrück: taż, Ravensbrück - kobiecy obóz koncentracyjny, Książka i Wiedza, Warszawa 1961, s. 97.

${ }^{21}$ W. Kiedrzyńska, dz. cyt., s. 108.

22 Tamże, s. 110.

${ }^{23}$ H. Amesberger, K. Auer, B. Halbmayr, dz. cyt., s. 80.
} 
w dezynfekującym płynie. Czynność tę wykonywały najczęściej więźniarki Żydówki ze Słowacji w obecności SS-manów. Nie należały jednak do rzadkości przypadki, kiedy funkcję tę spełniali mężczyźni”24.

Warto już na wstępie odnotować bezcelowość niektórych z wymienionych zabiegów i brak konsekwencji w podejmowaniu decyzji o ich przeprowadzaniu, zwłaszcza że będzie się to powtarzać w wielu sytuacjach. Przy tym „,bezcelowość" nie jest chyba słowem najwłaściwszym, ponieważ „dezynfekcyjnym” działaniom towarzyszył niewątpliwie cel, jakim było jeszcze jedno upokorzenie uwięzionych. Tym dotkliwsze, że związane z intymnym aspektem cielesności i jednocześnie piętnujące $\mathrm{w}$ rzucający się w oczy sposób. Bywało, że towarzyszyła mu dodatkowa doza perfidii. „Niszczono przede wszystkim włosy tym kobietom, które miały je najlepiej utrzymane" 25 - relacjonowała była więźniarka Auschwitz Elżbieta Sobczyńska.

Więźniowie rozmaicie reagowali na golenie ciała, ogólnie rzecz biorąc, mężczyźni łatwiej je znosili. Ale i w narracjach kobiecych prześledzić możemy rozmaite reakcje. I nie zawsze dramatyzm jest ich dominantą. Maria Elżbieta Jezierska, na podstawie opowieści Haliny Fronczak, zrelacjonowała historię pierwszego transportu więźniarek pawiackiej Serbii, wywiezionych do Birkenau ${ }^{26}$ :

Teraz moment nader przykry. Okazuje się, że tu wszystkim bez wyjątku ostrzygą głowy na zero. Bez względu na to, czy która ma wszy. Próżno piękna Fiodorowicz o długich lokach broni się jak może - pierwsza odchodzi spod nożyc z nagą, ohydną czaszką. Nagle - głośny, nerwowy, chóralny śmiech. Tylko jedna Fiodorowicz płacze: łzy upokorzenia i kobiecej próżności. A teraz, popatrzcie, ta druga! Grzesiowska wygląda zupełnie jak mężczyzna. Zaraźliwy, histeryczny śmiech - aż łzy w oczach ze śmiechu. Jakże się nie śmiać z ogolonych pałek! Ta ma głowę jak dynia, ta - jak niemowlę, a ta wygląda jak stateczny ksiądz proboszcz. Zugangi śmieją się. Patrzcie, te schodki po tępych nożyczkach! Jakże się nie śmiać z wyskakujących zza kotarki nagich, białych, całkiem ostrzyżonych ciał o ciemniejszych twarzach i o paznokciach tak bezsensownie, tak wolnościowo pomalowanych lakierem, czerwonym niby krew! !7

Trudno oczywiście dzisiaj wyważyć, ile w tej „radości” jest histerii na podłożu przeżywanej grozy. A oto Auschwitz, blisko rok później, w maju 1943 roku, w relacji Ireny Perkowskiej Szczypiorskiej:

${ }^{24}$ L. Cebo, Więźniarki w obozie hitlerowskim w Oświęcimiu-Brzezince, Wydawnictwo Uniwersytetu Śląskiego, Katowice 1984, s. 18.

${ }^{25}$ Archiwum Państwowe Muzeum Auschwitz-Birkenau, Zespół Oświadczenia, t. 75, k. 152.

${ }^{26}$ Było to 24 sierpnia 1942 roku. Zob. D. Czech, Kalendarz wydarzeń w KL Auschwitz, Wydawnictwo Państwowego Muzeum w Oświęcimiu-Brzezince, Oświęcim 1992, s. 236.

${ }^{27}$ M.E. Jezierska, Pierwszy warszawski, w: Kominy. Oświęcim 1940-1945, przedm. T. Hołuj, Czytelnik, Warszawa 1962, s. 133. 
Trudno opisać, jakie ogarnęło nas przerażenie. Do końca życia nie zapomnę tych scen. Pewna młoda, około szesnastu lat, dziewczyna, o nieprzeciętnej urodzie, która miała złociste, jasne loki, jak prawdziwa księżniczka z bajki, na widok tych ogolonych głów rozpłakała się rzewnymi łzami i choć ją pocieszałyśmy, tłumacząc, że najważniejszą rzeczą jest zachować głowę, bo włosy przecież odrosną - długo nie mogła się uspokoić i zapanować nad sobą. Dziewczyna ta [załamała się i] umarła po sześciu tygodniach pobytu w obozie. Wszystkie bez wyjątku byłyśmy tym widowiskiem wstrząśnięte, ale muszę przyznać, że mimo to nie mogłyśmy powstrzymać śmiechu, kiedy zbliżyła się do nas Walentyna Kielanowska. Nie, ona nie płakała, ale z siebie zakpiła. Z przekomiczną miną, nic nie mówiąc, wyciągnęła zza pazuchy mały węzełek, rozsupłała go i wyłożyła przed nami zakrętki [wałki] do [zakręcania] włosów ${ }^{28}$.

Jednak zdecydowanie najczęściej procedura przyjęcia była dla kobiet szokiem. W relacji więźniarki Ravensbrück, najprawdopodobniej ze wspomnianego już krakowskiego specjalnego transportu z 1941 roku, widać, że zaznaczone m.in. ogoleniem przejście w stan więźniarski wiąże się z długotrwałym psychicznym kryzysem.

Wstrząs, jakiego doznałam na wstępie (ogolenie głowy, pobyt trzy doby w podziemiach bunkra) odbił się na moim systemie nerwowym. Straciłam możność ciągłego, logicznego myślenia. Nie mogłam rozmawiać, gdyż rozpoczęte zdanie urywało się (częściowa afazja). Taki stan trwał szereg tygodni ${ }^{29}$.

Wprost powie Antonina Piątkowska (osadzona w Auschwitz-Birkenau w sierpniu 1942 roku):

Brak bielizny czy choćby chustki do nosa, ciężkie holenderskie drewniaki zamiast butów, tatuowanie numeru, ogolenie głowy u wielu nowo przybyłych powodowało już na początku tak wielki szok, że otrząśnięcie się z niego wymagało ogromnej siły psychicznej. Dodać trzeba, że dla kobiet ogolenie głów było chyba najtrudniejsze do zniesienia $^{30}$.

Trudno nie zauważyć, że polskie autorki wspominające ten etap procedury przyjęcia, który związany był z włosami, najczęściej używają uogólniającego słowa ,golenie”, mówią o ,pozbawieniu włosów” albo o goleniu tylko głowy.

${ }^{28}$ I. Perkowska-Szczypiorska, Kartki z Oświęcimia, w: Kominy..., s. 88-89.

${ }^{29}$ Zwyciężyly wartości. Wspomnienia z Ravensbrück, oprac. U. Wińska, Wydawnictwo Morskie, Gdańsk 1985, s. 22.

${ }^{30}$ A. Piątkowska, Wspomnienia oświęcimskie, przedm. J. Masłowski, Wydawnictwo Literackie, Kraków 1977, s. 78. 
Decyduje tu najprawdopodobniej wstydliwa powściągliwość albo zgoła unik przed wyartykułowaniem wprost, że golono i dezynfekowano też pachy, wzgórek łonowy i krocze. Bardzo rzadko napotkać można relację oddającą techniczną stronę tego zabiegu. A przecież golona kobieta musiała wówczas stanąć nago w rozkroku na dwóch taboretach, przed siedzącym przed nią fryzjerem lub fryzjerką. Przy tym cały czas używano tych samych, tępych i nie sterylizowanych w żaden sposób narzędzi. Wiedza o przebiegu ,procedury golenia” nie pozwala uznawać jej za rutynową czynność o charakterze higienicznym i porządkowym, ale za gwałt o charakterze seksualnym, poniżenie i uprzedmiotowienie. Zrozumiała też staje się głębia i ostrość tego upokorzenia.

Tak, to była najgorsza rzecz jaka mi się przytrafiła. No cóż, tak można oceniać jak złe to było. To było straszne. Ponieważ czujesz się jak, jak zwierzę, jak jakiś karaluch, na którego można nadepnąć $\mathrm{i}$ - to jest straszne. To naprawdę było straszne. Chodzi mi o to, że kiedy mówię, że to było straszne, nie o to chodzi, że ktoś mi coś zrobił, albo, że to bolało, kaleczyło, to golenie włosów. Ale to poniżenie, to było okropne. Po prostu to z nami zrobiono ${ }^{31}$.

Włoska Żydówka, Elisa Springer, przywieziona w sierpniu 1944 roku do Auschwitz (miała wówczas 26 lat), opisuje, jak odbywało się golenie kobiet, którym uprzednio kazano się położyć. To obraz dotąd nie odnaleziony przeze mnie w innych narracji lagrowych, wprost ujawniający dokonanie gwałtu:

Po skończonej selekcji, po rozdzieleniu kobiet i mężczyzn, wprowadzono nas do dwóch różnych baraków. I tu dokonano tej wstrętnej przemiany, którą można by nazwać początkiem depersonalizacji. Kazano nam rozebrać się do naga w obecności kilku esesmanek i strażniczek uzbrojonych w pałki, kobiet o twarzach złych - i pozbawionych wszelkich uczuć. Potem położono nas na takich jakby lekarskich tapczanach i wygolono do zera we wszystkich częściach ciała. Robili to więźniowie w białych fartuchach, którzy znali się trochę na fryzjerstwie. Nie otwierali ust, ale z ich milczenia można się było domyślić, że czynili to pod przymusem. Wszystko się przeciw mnie buntowało przeciwko takiemu pogwałceniu mojej intymności, w pewnej chwili ścisnęłam nogi i zasłoniłam ramionami piersi. Eskortujący nas esesman dźgnął mnie lufą karabinu i wrzasnął: „Rozewrzyj nogi i daj się wygolić!”. I w tym momencie straciłam całą swoją godność i wyzbyłam się wstydu. [...] Byłyśmy Żydówkami, istotami nieczystymi, przeznaczonymi do eliminacji: takie było żelazne prawo Reichu ${ }^{32}$.

${ }^{31}$ Cyt. za: H. Amesberger, K. Auer, B. Halbmayr, dz. cyt., s. 82. Przytoczony fragment podaję we własnym tłumaczeniu.

${ }^{32}$ E. Springer, Milczenie żywych. W cieniu Auschwitz, opowieść o śmierci i zmartwychwstaniu, tłum. K. i E. Kabatcowie, Państwowe Muzeum Auschwitz-Birkenau, Oświęcim 2001, s. 72-73. 
Wygłosowe zdanie tego fragmentu stanowi gorzką i demonstracyjną projekcję ideologii nazizmu na własną osobę, jest autoironicznym odreagowaniem traumy. Odkrywa przy tym symboliczny charakter zabiegu pozbawienia włosów, jakiemu zaraz po przybyciu do obozu poddawane były niektóre więźniarki. Interesują mnie przede wszystkim praktyki, jakim poddawane były kobiety i ich emocjonalna na nie odpowiedź - to właśnie ona wydobywa często dodatkowy, znaczący wymiar konkretnych sytuacji. Nie sposób powiedzieć, na ile oprawcy zdawali sobie sprawę z symbolicznego charakteru operacji golenia ${ }^{33}$. Tradycja rytualnego pozbawiania włosów sięga bardzo głęboko w dzieje ludzkich społeczności, ale nie należy się chyba spodziewać, że obozowym praktykom upokarzania więźniów towarzyszyła tego intelektualna świadomość (około połowa niemieckiego personelu miała wykształcenie jedynie podstawowe). Raczej nabyte wraz z nazistowskim przekazem propagandowym przekonanie, że mają oni do czynienia z Untermenschen, co modelowo ujawniało się np. przy okazji odbywających się też poza obozem ,spektakli” golenia głowy kobietom i mężczyznom oskarżonym o przekroczenie zakazu separacji rasowej.

Na pewno przynajmniej w części, jak głosiło oficjalne uzasadnienie, golenie włosów podyktowane było względami higienicznymi. Niemcy bali się wszy i przenoszonego przez nie tyfusu. $Z$ drugiej strony masowe akcje odwszenia w obozie przeprowadzane były niechlujnie, bez dbałości o ich skuteczność. Stanowiły raczej jeszcze jedną formę eksterminacji, mniej zaś operację prewencyjną. Niemniej zarządzenia dotyczące golenia włosów miały charakter w pewnym stopniu porządkujący i, w gruncie rzeczy, przez przemoc oraz dominację określały pozycję więźniarek. Wspomnienie Marii Rutkowskiej-Kurcyuszowej z Ravensbrück wyraźnie oddaje ten dodatkowy aspekt przejścia w stan więźniarski: „defilada nagich, drżących, oszołomionych własną bezbronnością kobiet przed gromadą esesmanów, była celnie obmyślanym obrzędem wstępnym do obozowego życia" ${ }^{4}$. Dlatego wymowne jest odniesienie procedury przyjęcia z goleniem włosów do poszczególnych grup narodowościowych, wprost określały one podrzędność Żydówek i Rosjanek, Polek względem innych narodowości i instrumentalnie - poprzez widoczny z daleka stygmat łysej głowy - wskazywały je jako przedmiot eksterminacji. Wciąż pamiętać trzeba, że w konkretnych przypadkach golenie zależało od obozu, daty przybycia, ale przede wszystkim od arbitralnej, tzn. często przypadkowej decyzji SS.

Obrzędowy i symboliczny charakter tego procederu paradoksalnie podkreślany był też przez brak jego zastosowania wobec, nazwijmy to, wyjątkowych więźniów. Trudno sobie wyobrazić, aby ogolona być mogła np. Karolina Lanckorońska,

\footnotetext{
${ }^{33}$ Relacjonują to np. Kazimierz Banek (Opowieści o włosach. Zwyczaje, rytuaty, symbolika, Trio, Warszawa 2010), prace Emila Durkheima, Jamesa Frazera, Ervinga Goffmana, Harolda Garfinkela.

${ }^{34}$ M. Rutkowska-Kurcyuszowa, dz. cyt., s. 148.
} 
przebywająca w Ravensbrück w wybitnie komfortowych, jak na obóz koncentracyjny, warunkach ${ }^{35}$. Na podobnej zasadzie procedura przyjęcia pomijała golenie w obozie dla jeńczyń wojennych, który to status uzyskały uczestniczki powstania warszawskiego. Przesiedlenie do obozu przejściowego Mosdorf (po uwięzieniu w Lamsdorf) nie wiązało się z goleniem głowy, ale kąpielą i odwszawianiem. Choć kobiety umieszczone w stalagu i oflagu posiadały swobody nieporównywalne z więźniarkami obozów koncentracyjnych, np. zachowywały prywatne rzeczy, nie były eksploatowane przez prace przymusowe i nie ciążył nad nimi codzienny terror KL, i one poddają się znanym doskonale emocjom: bezradności, upokorzenia, wstydu. Nieco inaczej jednak niż zwykle w obozach koncentracyjnych zachowuje się niemiecki męski personel.

Rozebrałyśmy się - i w przeciągu dwóch czy trzech minut stałyśmy się kimś innym, niż byłyśmy dopiero co. Weszłyśmy tu jako zorganizowana grupa o ważnym dla nas i wiadomym dla naszych dozorców statusie wojennym. Teraz stało przed nimi anonimowe zbiorowisko nagich kobiet. Sparaliżowane upokorzeniem i drżące z zimna czekałyśmy, co dalej. [...] Rozkaz przejścia do sąsiedniego pomieszczenia przyniósł ulgę. Czekało nas tam „odwszawianie”. Moczenie włosów w misce ze śmierdzącym płynem wydało mi się zresztą czymś o wiele mniej dotkliwym niż ponure przedstawienie [kąpiel - B.Cz.], w którym byłyśmy groteskowymi aktorkami, a wachmani i funkcyjni publicznością. Tym ostatnim należy się za to zresztą parę ciepłych słów. Od pierwszej do ostatniej chwili wyraźnie skrępowani sytuacją, w której kazano im pracować [...], odnosili się do nas nie tylko z życzliwością, ale i wzruszającą w naszej idiotycznej sytuacji dyskrecją. [...] „Odwszawionym” (bardzo nielicznym to było potrzebne) i wymytym znowu kazano czekać, tym razem na ubrania ${ }^{36}$.

Egzystencja w lagrze wiązała się z ustaleniem nowych praktyk obozowego życia społecznego. Odrastanie włosów było tam miarą upływu czasu, oznaczało wyjście poza status Zuganga i osadzenie, zakorzenienie w życiu obozowym ${ }^{37}$.

Osobny przedział lagrowego doświadczenia stanowiły akcje odwszawiania, tutaj nie podnoszę szerzej tego zagadnienia. Odwszenia, właściwie pozbawione higieniczno-medycznego sensu, były raczej szykanami i jeszcze jedną formą eksterminacji - rozebrane kobiety bywały np. trzymane na mrozie przez kilkanaście godzin. Otrzymywały potem wciąż jeszcze zawszoną (nawet jeśli wybite zostały żerujące insekty, w zakamarkach ubrań pozostawały gnidy, z których po kilku go-

${ }^{35}$ K. Lanckorońska, Wspomnienia wojenne. 22 IX 1939 - 5 IV 1945, słowo wstępne L. Kalinowski i E. Orman, Znak, Kraków 2001.

${ }^{36}$ I. Jurgielewiczowa, Strategia czekania, Państwowy Instytut Wydawniczy, Warszawa 1982, s. $117-118$.

${ }^{37}$ Taka miara upływu czasu i ewolucji Zuganga w tzw. stary numer pojawia się też w literaturze i świadectwach mężczyzn. 
dzinach wylęgały się wszy), ale już cudzą odzież, nieraz jeszcze skutecznie trującą cyklonem. Akcja odwszawiania wykańczała chore, pozbawione sił więźniarki. Zdrowe miały jeszcze jedną okazję, aby „w najlepszym wypadku” przeziębić się.

Wraz z przyjmowaniem na kobiecy rewir w KL Lublin polski personel starał się przeglądać głowy, jeśli kobiety były zawszone, golono je. Danuta Brzosko-Mędryk w obozowej biografii Wandy Ossowskiej (książka Matylda) opowiada o stopniu zawszenia tych, które nie miały siły walczyć o higienę. „Przepuściłam kiedyś chorą, bardzo chorą Rosjankę bez przejrzenia włosów. Były chyba centymetrowej długości. Kiedy podeszłam do niej po pół godzinie, przerażona ujrzałam prawie łysą czaszkę - to co uważałam za włosy, było warstwą wszy"38.

Kobiety w ramach dostępnych możliwości szukały sposobów pozbycia się insektów i odzyskania zdrowej skóry głowy. Podstawowym zabiegiem było wzajemne iskanie, sposobem na uzyskanie jakiejkolwiek aseptyki bywała urynoterapia. Opowiadała Urszula Kisiel, więźniarka toruńskiego obozu zwanego Szmalcówką: „My leczyliśmy się własnym moczem zewnętrznie i wewnętrznie. Jak ja miałam całą głowę w ropie z wszami, to inni, żeby mnie uleczyć, sikali mi na głowę" ${ }^{39}$. Taka wzajemna pomoc w zakresie higieny i „,medycyna” stanowi dowód bardzo specyficznej, obozowej więzi między kobietami. To nie tylko znane z literatury historycznej ,,rodzinki”, ale również wachlarz zróżnicowanych relacji od czysto seksualnych, przez rozmaite odcienie relacji angażujących także ciało, do absolutnie silnych ,więzi przetrwania”, pozostających na całe życie, ważniejszych od późniejszych związków z mężczyznami (tak, jak związek dwóch bohaterek powieści Przejście przez Morze Czerwone Zofii Romanowiczowej). Wzajemne iskanie, czesanie ${ }^{40}$, pomoc przy myciu głowy niewielką ilością przeznaczonych do picia „ziółek” były formą siostrzeństwa czy właśnie więzi przetrwania. Jedną z ikon tych relacji może być wykonany przez Marię Hiszpańską w 1944 roku w obozie Ravensbrück rysunek ołówkiem Tępienie wszy w obozie Ravensbrück ${ }^{41}$. Przedstawia on dwie więźniarki, jedną w pozycji siedzącej, widoczną z profilu, drugą w pozycji leżącej, widoczną od przodu, opartą na łokciu i ramieniem o kolana pierwszej. Siedząca kobieta pochylona jest nad głową leżącej, palcami przebiera jej włosy. Choć ta scena przedstawia iskanie, to jednak emfatyczna bliskość kobiet i ich zatopienie w wykonywanej czynności paradoksalnie odgradzają je od szaleństwa i grozy obozowych realiów.

${ }^{38}$ D. Brzosko-Mędryk, Matylda, s. 136-137.

${ }^{39}$ Cyt. za: T.S. Ceran, Szmalcówka, Instytut Pamięci Narodowej, Bydgoszcz-Gdańsk 2010, s. 85.

${ }^{40} \mathrm{~W}$ literaturze lagrowej i świadectwach kobiet znaleźć można wiele przedstawień podobnych sytuacji: „Zapamiętałam stamtąd [Ravensbrück, blok czeski, rok 1943 - B.Cz.] błahostkę, dziwny obrazek na tle życia w obozie, świadczący o spokoju, jaki panował w tym baraku. Codziennie o świcie przed apelem jedna z Czeszek czesała długie blond włosy Maryli, która upinała je w ciężki węzeł na tyle głowy”, A. Truszkowska-Kuliniczowa, dz. cyt., s. 120.

${ }^{41}$ Kopia rysunku jest eksponowana w gdańskim Muzeum II Wojny Światowej, w części ekspozycji poświęconej obozom koncentracyjnym i zagłady. 
Element nazistowskiego reżimu, jakim było golenie $\mathrm{w}$ ramach procedury przyjęcia $\mathrm{w}$ stan obozu, szczególnie silnie godził w kobiety. $\mathrm{Z}$ tego powodu pozbawianie włosów odgrywało jedną z kluczowych ról w systemie stosowanych wobec nich kar. Wymieniony już wcześniej Michał Piotrowski, jako więzień męskiego sektora Ravensbrück, obserwował sąsiadującą z nim kobiecą część obozu: „W KL Ravensbrück jednakowo traktowano kobiety i mężczyzn, nie czyniono między nimi żadnej różnicy. Za byle głupstwo ścinano kobietom włosy do gołej skóry" ${ }^{\prime 2}$.

Spośród licznych kar stosowanych w tym obozie wobec Polek Wanda Kiedrzyńska wymienia także golenie głowy za stosunek z Niemcem. Czystość rasy miała obowiązywać też Niemki. W marcu 1940 roku Himmler postulował dla niemieckich kobiet za „niehonorowe zachowanie”, czyli stosunki z robotnikami przymusowymi z krajów podbitych, publiczne kary, które miały działać odstraszająco, szczególnie wobec młodzieży. Kara miała polegać na ogoleniu głowy, a następnie przeprowadzeniu karanej kobiety przez całą wieś, z tabliczką na szyi, na której opisano przewinienie ${ }^{43}$. Urszula Wińska relacjonowała dręczenie politycznej więźniarki narodowości niemieckiej:

W 400-osobowej kolumnie kobiet różnych narodowości byłaby uszła mojej uwagi, gdyby nie świeżo ogolona głowa (do końca pozostałam wrażliwa na ten szczegół operacji obozowych). [...] Wiedziałyśmy, że golenie głów Niemkom było karą za niedozwoloną miłość z cudzoziemcem. Ta kobieta nie wyglądała na takie przestępstwo $^{44}$.

Jak okazało się później, Niemka odbywała w obozie karę za złamanie obowiązującego w III Rzeszy dnia bezmięsnego - nakarmiła syna, który ranny wrócił do domu $\mathrm{z}$ frontu wschodniego.

W obozie ogolili jej głowę i dostała 25 batów wymierzonych przez maszynę. Po miesiącu mogłaby już iść do domu, ale nie wytrzymała przepisanej kary [zemdlała w trakcie chłosty - B.Cz.]. Po ponownym ogoleniu wytrzymała tylko 15 uderzeń. [...] Po dwóch latach, w styczniu 1945 roku, spotkałam ją na rewirze. [...] Poznałam ją po świeżo ogolonej głowie ${ }^{45}$.

Urszula Wińska opisuje też fakt dotyczący innej niemieckiej więźniarki:

${ }^{42}$ M. Piotrowski, dz. cyt. s. 91.

${ }^{43}$ H. Amesberger, K. Auer, B. Halbmayr, dz. cyt., s. 80.

${ }^{44}$ Serca niezagaste. Wspomnienia więźniarek z Ravensbrück, wybór M. Kogut-Piotrowska i A. ierczak, oprac. A. Gierczak, wstęp J. Zaborowski, Wydawnictwo Ministerstwa Obrony Narodowej, Warszawa 1979, s. 175-176.

45 Tamże, s. 176. 
Miała ogoloną głowę. Zapytana o przyczynę, odparła: - [...] Ponieważ byłam człowiekiem. Zbierała w ogrodzie jabłka. [...] Jeńcy wojenni przechodzili tamtędy i pożądliwie spoglądali na owoce. Wysypała im przez płot kosz jabłek. [...] W dwie godziny później zabrało ją gestapo ${ }^{46}$.

Szczególne wrażenie robi wspomnienie sytuacji, która utrwalona została w wielu przekazach literackich i świadectwach byłych więźniarek Auschwitz-Birkenau. Oto relacja Antoniny Piątkowskiej, warto zacytować dłuższy jej fragment:

Przed powrotem do obozu esesmani przeliczali komando. Okazało się, że w naszej grupie brak więźniarki z Łodzi, oznaczonej zielonym trójkątem, a więc niepolitycznej. Całą naszą kolumnę przepędzono biegiem przez bramę obozu, gdzie esesmani zameldowali o ucieczce więźniarki. Wprowadzono nas do obozu. Po jakimś czasie zjawiła się cała elita obozowa: komendant Rudolf Hoess, szef oddziału politycznego Grabner, słynny morderca Gerhard Palitzsch, Hans Aumeier i wielu innych. Kazano nam stać na baczność i pilnowano tak, że nie można było nawet drgnąć. Gestapowcy zapowiadali, że zostaniemy zdziesiątkowane. Było nas 200 Polek, a więc 20 musiało zginąć. Groźby powtarzały się wraz z krzykiem i wymysłami, ale nam było wszystko obojętne. Niech Niemcy strzelają, zamiast godzinami opowiadać, że będą strzelać. Stałyśmy zupełnie nieruchomo, patrząc prosto w oczy gestapowcom, nie drgnęły i nie załamały się nawet te, które dokładnie wyliczyły sobie, że przy odliczaniu co dziesiątej więźniarki pójdą na śmierć.

Tymczasem po kilku godzinach nadeszła telefoniczna decyzja z Berlina, że uciekinierka nie była więźniem politycznym, więc Polki nie zostaną zdziesiątkowane, ale za karę mają mieć wszystkie zgolone włosy i wysłane do karnej kompanii w Budach [tzw. Strafkompanie]. I kiedy Hoess Kazał przetłumaczyć to zarządzenie, raptem wśród kobiet powstało nieopisane zamieszanie. Te same kobiety, które tak spokojnie, tak bohatersko oczekiwały śmierci, w jednym momencie załamały się na wiadomość, że... mają mieć ogolone głowy. Nic to dla nich nie znaczyło, że otaczają je gestapowcy, że cały sztab Oświęcimia stoi przed nimi. Krzyczały, że nie pozwolą sobie obciąć włosów, płakały, rozpaczały. Zamieszanie stawało się coraz większe, zupełnie nie do opanowania, tak że gestapowcy w pewnym momencie odeszli, zostawiając nas tylko pod nadzorem SS-Aufseherinnen (dozorczyń). Te zresztą też nie zdradzały ochoty do gwałtowniejszego wystąpienia, zleciły tylko blokowej i kapo wykonanie zarządzenia, a same wolały się nie zbliżać do rozwścieczonych, zdesperowanych więźniarek. Wieczne kobiety... Dla nich nie śmierć była najstraszniejsza, ale oszpecenie. Wobec konieczności oszpecenia podniosły bunt, bunt rozpaczliwy, nie zważając na żadne konsekwencje ${ }^{47}$.

\footnotetext{
${ }^{46}$ Tamże, s. 177.

${ }^{47}$ A. Piątkowska, dz. cyt., s. 52.
} 
Długo wydawało mi się, że sceny te w sposób ikoniczny przedstawiają temat włosów kobiet uwięzionych w lagrach. Za szczególnie wymowne, wręcz porażające, uważałam zachowanie spokoju wobec groźby zdziesiątkowania i histerię po ogłoszeniu kary zgolenia włosów. Jednak wydany przed kilkoma miesiącami wywiad rzeka Michała Wójcika z Zofią Posmysz, uczestniczką tych samych wydarzeń, osłabił to wyidealizowane wyobrażenie:

Wreszcie rozkaz: wymarsz do Bud. Od razu. A Budy to podobóz, kilka kilometrów za głównym obozem. Obóz Strafkompanie, w skrócie SK. Dopiero potem usłyszałam, że odbyły się konsultacje z Berlinem. I uratowało nas to, że uciekinierką była więźniarka kryminalna, nie polityczna. Podobno po raz pierwszy Niemcy nie zastosowali dziesiątkowania. Litościwi. [...] Wtedy nam ścięto włosy. Dopiero wtedy. Ale my byłyśmy tak otępiałe, że to na żadnej z nas nie zrobiło silnego wrażenia ${ }^{48}$.

I w odniesieniu do podejmowanego tu przeze mnie zagadnienia okazuje się, że konfrontacja źródeł może przynieść nieoczekiwane efekty.

Wiele kobiecych narracji pokazuje, że w obozowym społeczeństwie kobiet, więźniarek, funkcyjnych i strażniczek, wielokrotnie dochodziły do głosu takie emocje jak zawiść lub zazdrość. Pamiętamy tragiczną historię ładnej (i obdarzonej lokami) dziewczyny Lily, bohaterki opowiadania Liany Millu Lily Marlene z tomu Dymy Birkenau ${ }^{49}$. Inną, ale również opartą na zazdrości sytuację wspominała piętnastoletnia żydowska dziewczyna Zofia Minc:

Tej nocy po raz pierwszy odkąd byłam w Oświęcimiu, ktoś mi pomógł. Był to capo niemiecki, zbrodniarz, który dostał dwanaście lat więzienia. Opowiedziałam mu, że mam chorą matkę, to zaniósł jej biały chleb. [...] Poszłam do pracy sama, ale aufseherka zauważyła, że mnie capo niemiecki pomaga i za karę zaraz mi zgoliła włosy, które już mi już nieco odrosły, i kazała skakać w kucki naokoło garderoby ${ }^{50}$.

Warto zwrócić uwagę na jeszcze inny charakter karnego ścięcia włosów. Tym razem dotyczy ono Polki z obozu w Ravensbrück, ochotniczej kandydatki do puffu i dokonane zostało przez polskie współwięźniarki. O zdarzeniu wspo-

${ }^{48}$ Z. Posmysz, Królestwo za mgła, Znak, Kraków 2017, s. 86. Ta sytuacja, ale odmiennie ukazana, powraca też w fabularyzowanych wspomnieniach Zofii Posmysz: „Dotknęła nas boleśnie strata włosów. SK? Strafkompanie? To nam nic nie mówiło”, Z. Posmysz, Ten sam doktor M, Iskry, Warszawa 1981, s. 16-17.

${ }^{49}$ L. Millu, Dymy Birkenau, przeł. K. i E. Kabatcowie, Państwowe Muzeum Auschwitz-Birkenau, Oświęcim 2007.

${ }^{50}$ Dzieci żydowskie w czasach Zagłady. Wczesne świadectwa 1944-1948. Relacje dziecięce z Centralnej Żydowskiej Komisji Historycznej, oprac. O. Orzeł, przekł. E. Bergman, P. Kendziorek, K. Szymaniak, Żydowski Instytut Historyczny im. Emanuela Ringelbluma, Warszawa 2014, s. 198. 
mina nie tylko Wanda Kiedrzyńska w monografii obozu; odczytajmy relację pióra Stanisławy Młodkowskiej-Bielawskiej:

Komendant obozu zwołał pewnego dnia wszystkie więźniarki na plac obozowy i bezczelnie zaproponował nam, że jeśli któraś chce mieć lepsze wyżywienia i warunki, niech się zgłosi na wyjazd do domu publicznego. My więźniarki polityczne uważałyśmy to za wielką obelgę i z oburzeniem odwróciłyśmy się i w szeregach odeszłyśmy do bloków. Kilka młodszych, gdy dowiedziały się, że jakaś Polka zgłosiła się na wyjazd, napadły ją wieczorem i obcięły jej włosy. Trochę ją przy tym pokaleczyły, gdyż nożyce były tępe ${ }^{51}$.

Sytuacja miała miejsce w roku 1944. Zdaje się ona ujawniać kilka znaczeń, np. różnice pomiędzy rygorem różnych obozów w różnym czasie. Nie sposób wyobrazić sobie, aby w roku 1941 albo 1942 w Auschwitz więźniarki mogły pozwolić sobie na samowolne i bez konsekwencji oddalenie się. Przedstawiona sytuacja ma też inny wydźwięk. Jest argumentem na rzecz etosowych postaw Polek, które w akcie ogolenia innej więźniarki tej samej narodowości wyraziły swój sprzeciw wobec hańbienia polskości. Golące więźniarki widzę tymczasem w dwuznacznej roli: jako więźniarki-oprawczynie w pewnym stopniu współdziałające z obozowym systemem przemocy i upokorzenia.

W obozie zabroniono samowolnie manipulować włosami, nawet jeśli było to tylko niewielkie podcięcie, tym bardziej we wzorcowym jeszcze w 1941 roku Ravensbrück. Wanda Kiedrzyńska streszcza historię jednej z więźniarek: „W styczniu 1941 roku, podczas 20-stopniowego mrozu, skazano 18-letnią Henrykę Derasównę za podcięcie włosów na 2 tygodnie bunkra. Siedziała w nie opalanej ciemnicy, o chlebie i kawie, obiad co czwarty dzień. Po wyjściu, na skutek odmrożenia nóg, nastąpiło zakażenie i pomimo amputacji Derasówna zmarła" ${ }^{\prime 2}$.

Więźniarki same starały się zapobiegać wszawicy przez nielegalne obcinanie długich włosów. Halina Birenbaum znalazła się na Majdanku (potem były Auschwitz, Ravensbrück i Neustadt-Glewe) w wieku 13 lat (rok 1943). Miała wtedy długie włosy, które matka upinała jej w koronę, co dodawało dziewczynce lat, czyniło ją zewnętrznie dojrzalszą, a tym samym chroniło przed losem przeznaczonym dla dzieci. Ale po zagazowaniu matki nie miał kto pielęgnować jej włosów, poza tym - piękne i rzucające się w oczy - narażały na ryzyko zawiści funkcyjnych lub strażniczek, a nawet na śmierć. Dlatego włosami Haliny zajęła się szwagierka Hela. „Kiedy weszliśmy na teren Majdanka, odbywał się tam apel [...], tymczasem Hela pożyczyła od kogoś ukradkiem nożyczki, które

${ }^{51}$ S. Młodkowska-Bielawska, Wspomnienia okupacyjne, oprac., wstępem i przypisami opatrzył oraz podał do dr. R. Stopikowski, Wydawnictwo KUL, Lublin 2001, s. 60.

${ }^{52}$ W. Kiedrzyńska, dz. cyt., s. 48. 
przechodziły w czasie apelu z rąk do rąk; szybkim zręcznym ruchem obcięła mi oba warkocze i nogą zagrzebała je natychmiast w ziemi. [...] Przyjęłam te postrzyżyny z całkowitą obojętnością"53. Być może więcej dramatyzmu ma w sobie ten, przyjęty z otępiałą obojętnością 13-latki, pochówek jej włosów na placu podczas apelu, niż postrzyżyny, które zostały głośno opłakane. Nierytualnie, w zgoła niepatetycznych okolicznościach dokonał się jakby symboliczny pogrzeb dziewczęcości, młodości i niewinności.

Włosy, w sposób widoczny na pierwszy rzut oka, odróżniały świat wolnościowy od obozu. W prozie poetyckiej Charlotte Delbo odsłania się obraz miasta Oświęcim, przez które przemaszerowuje grupa więźniarek: „Miasto, którym szłyśmy / było dziwnym miastem. / Kobiety nosiły kapelusze / kapelusze włożone na włosy / w lokach. / Miały również buty i pończochy / jak w mieście" 54 . To w zasadzie oczywiste wyliczenie, czego nie mają więźniarki (kapeluszy, włosów, butów i pończoch), oddaje nie tylko obozową nędzę, ale i inny psychiczny status kobiecości w obozie - pozbawionej jej atrybutów, odartej z atrakcyjności i upokorzonej. To także dramat przepaści dzielącej światy tych dwóch „rodzajów” kobiet - więźniarek i mieszkanek Oświęcimia z ich włosami ufryzowanymi w loki, ozdobionymi kapeluszami. Ale szerzej to także obraz rozłamu cywilizacyjnego i głębokiego napiętnowania, jakiego dokonała wojna i obozy koncentracyjne. Nie wystarczy po oswobodzeniu zakręcić włosy i kupić kapelusz, aby powrócić do życia; z tego już wówczas Delbo chyba zdawała sobie sprawę. Niedługo potem swoje wspomnienia, spisane w 1946 roku, zatytułuje Żaden z nas nie powróci.

Włosy/brak włosów były/był znakiem przełamania życia na ,przed obozem” i „po obozie". Zachowane stanowiły nie tylko zasadniczy składnik kobiecej atrakcyjności, ale oznakę godności, która nie została naruszona. Ogolenie, nawet w oczach dotkniętych tym samym gwałtem współwięźniarek, stanowiło degradację, oznaczało odhumanizowanie, niwelowało naturalne prawa do wolnych emocji.

Nie widziała siebie. Nie wiedziała, w co zamienił ją zabieg golenia głowy. Nie była już ładna ani świeża, ani nawet młoda. Jej twarz ze sterczącą nad czołem szczeciną nierówno wystrzyżonych włosów była naznaczona piętnem hańby i nie budziła skojarzenia z pokrzywdzonym dzieckiem. Uśmiech na takiej twarzy wywoływał zgorszenie jako coś nieprzystojnego, nie przystającego do niej ${ }^{55}$.

${ }^{53}$ H. Birenbaum, Nadzieja umiera ostatnia, Państwowe Muzeum Auschwitz-Birkenau, Oświęcim 2014, s. 100.

${ }^{54}$ C. Delbo, Żaden z nas nie powróci, przeł. K. Malczewska-Giovanetti, Państwowe Muzeum Auschwitz-Birkenau, Oświęcim 2002, s. 141.

${ }^{55}$ Z. Posmysz, Ten sam doktor M, s. 19. 
W literackiej analizie Posmysz odsłania się mechanizm charakterystyczny dla gwałtu seksualnego i jego następstw, napiętnowania i degradacji.

Literatura i świadectwa obozowe w nawiązaniu do włosów pokazują, współcześnie już zatartą, różnicę płci. Wachsmann cytuje znaczące słowa: „z ogolonymi głowami wyglądałyśmy jak mężczyźni, zanotowała jedna z więźniarek w swoim dzienniku"56. Wobec ogolonych kobiecych głów bezradny stawał się zewnętrzny obserwator, niepewność wywołaną takim wyglądem kobiet oddaje relacja Norweżki Sylvii Salvesen: ,pierwszy raz w moim życiu widziałam istoty, o których nie mogłam powiedzieć, czy to są mężczyźni czy kobiety. Głowy miały ogolone, były wychudzone, brudne i złamane swoim nieszczęściem. Nie można o tym inaczej powiedzieć, jak tylko, że miały «śmierć» w oczach"57. Uderzająco podobny obraz i dylemat związany z utraconą wraz z włosami tożsamością płci ujawnia wiersz Primo Leviego: „Zastanówcie się, czy to jest kobieta / bez włosów i bez nazwiska / z pustką w oczach i wyschłym łonem, / jak zimowa żaba, / I nie ma już siły, by pamiętać"58. Podobnie powie i Szymon Laks, od lipca 1942 więziony w Auschwitz:

wzrok mój przyciągają dziwaczne postacie, krążące za drugim rzędem drutów. Co to za stworzenia? Istoty ludzkie? Karzełki? Dzieci? Kilka z nich podchodzi bliżej drutów i dopiero wtedy je rozpoznaję! Te stworzenia, odziane w znoszone sowieckie mundury, o wygolonych czaszkach i szarych wynędzniałych twarzach to kobiety! A raczej, to były kiedyś kobiety ${ }^{59}$.

Jak dalece kobiece włosy stanowiły unicestwiony w obozie element indywidualizacji, świadczy emocjonalne, a może nawet napełnione przeżytym szokiem, wspomnienie byłej więźniarki:

byłyśmy wysłane do miejsca, gdzie musiałyśmy pozbyć się całej naszej odzieży, zostawić ją na podłodze. Powiedzieli nam, że będziemy miały prysznic, my nie wiedziałyśmy nic o właściwym prysznicu ani o prysznicu, który nie był prysznicem. Doszłyśmy do tego miejsca i zaczęli nam golić włosy, to nie czyniło nam krzywdy i oni też nie czynili nam krzywdy, nie wtedy. Ale to było straszne być ogoloną przez tych SSmanów, którzy w żaden sposób nie zachowywali się źle. To nie byłoby w porządku, gdybym powiedziała, że wtedy coś nam zrobili. Ale ogolenie głowy było dla mnie jedną z najgorszych rzeczy, jakie mi się zdarzyły, ponieważ czujesz się wtedy bardziej niż naga, czujesz się zdegradowana. Tak, to było straszne. I wtedy poszłyśmy pod prysznic, dokładnie wystrzyżone i bez ubrań, bez niczego. Obok mnie stała

${ }^{56}$ N. Wachsmann, dz. cyt., s. 259.

${ }^{57}$ Cyt. za: W. Kiedrzyńska, dz. cyt., s. 58.

${ }^{58}$ P. Levi, Czy to jest człowiek?, przeł. H. Wiśniowska, Wydawnictwo Literackie, Kraków 1978, s. 7.

${ }^{59}$ S. Laks, Gry oświęcimskie, Państwowe Muzeum Auschwitz-Birkenau, Oświęcim 1998, s. 36. 
młoda kobieta, wystrzyżona jak ja, mówiła: „Gdzie jesteś Klaro? Gdzie jesteś?”. Odpowiedziałam: „No cóż, jeśli ty jesteś Marią, to stoję tuż obok ciebie”. Nie znałyśmy się nawzajem. Chcę powiedzieć, że to było okropne ${ }^{60}$.

Wygląd włosów, ich posiadanie lub też brak stanowią znaczący element kultury. Również wiele narracji obozowych wskazuje na włosy jako atrybut wytworzonej tam struktury społecznej. Zachowane włosy i ich stan odróżniały więźniarki funkcyjne, prominentki oraz nierzadko więźniarki polityczne od „zwykłych” häftlingów. Ufryzowane mogły też oznaczać przynależność do lepszego komanda, np. „,kanadyjek” w Auchwitz-Birkenau, w którym dostęp do rzeczy zrabowanych zamordowanym Żydom pozwalał na wykonanie fryzjerskich zabiegów ${ }^{61}$. Włosy, jako widoczny znak seksualnej atrakcyjności i specjalnego traktowania (np. większe porcje żywieniowe, osobny barak), miały też kobiety zatrudnione w obozowych puffach; los tych kobiet, sam w sobie, jest tematem na monografię. Jak dalece włosy znamionowały zajęcie określonego szczebla obozowej hierarchii oddaje literacka narracja Seweryny Szmaglewskiej:

Wtedy na progu zjawił się piękny mężczyzna z odkrytą głową. Jego kasztanowate, miękko sfalowane włosy lśniły całym bogactwem przywileju, jakim obdarzyły go władze pozwalające uniknąć strzyżenia na zero. Włosy w obozie to niemal aureola. Patrzyłem w jej blask wspaniały [...] kim on ostatecznie był? Konradem Wallenrodem? Czy zwykłym opryszkiem? Bezpośredni, naiwny, czasem bezczelny potrafił używać swoich atutów: urody, wygadania, przywileju długich włosów. Zauważyliśmy, że nowi esesmani, którzy weszli do załogi Oświęcimia w lecie 1944, szczególnie na ten ostatni atrybut Kurta byli wrażliwi. Dla nich funkcyjny z włosami przestawał być godny pogardy. Może na tle bezwłosych małpoludów obozowych wydawał się kimś wyjątkowym do kogo nie można gładko mówić Arschloch lub wrzeszczeć ferluchte Schwein. Zdarzało się ku naszemu zdziwieniu, że gestapowiec w rozmowie z Kurtem używał zwrotu „Sie" ${ }^{\prime 2}$.

Autorka opowiadania Wielkie róże to znaczy Gross-Rosen opisuje tu Kurta Reinholda, niemieckiego oberkapo, który osadzony w obozie za nadużycia podatkowe nie musiał nosić oznakowania „winklem”. „Przywilejowi temu towarzyszył jeszcze jeden: prawo zapuszczania sobie włosów" "63. Włosy w funkcji społecznej, by tak rzec, odsłaniają tu jeden z paradoksów zlagrowanego świata. $Z$ jednej strony, nazywany później wielokrotnie ,inną planetą”, ,innym światem”, ,antyświa-

${ }^{60}$ Cyt. za: H. Amesberger, K. Auer, B. Halbmayr, dz. cyt., s. 81.

${ }^{61}$ Zob. np. S. Laks, dz. cyt., s. 101.

${ }^{62}$ S. Szmaglewska, Wielkie róże to znaczy Gross-Rosen, w: taż, Chleb i nadzieja, Wydawnictwo Ministerstwa Obrony Narodowej, Warszawa 1960, s. 121-123.

${ }^{63}$ S. Laks, dz. cyt., s. 36. 
tem", dysponował jednocześnie mechanizmami spoza drutów, jego wewnętrzna struktura (np. hierarchia społeczna) nawiązywała do stereotypów i reakcji społecznych otoczenia.

Kiedy więźniarki z Kommanda Politische Büro weszły do baraku w asyście Aufseherin - wszystkie spojrzenia skierowały się $\mathrm{w}$ ich stronę. Wyglądem swoim wprowadziły nas $w$ zdumienie. [...] miały na sobie czarne, jedwabne, zręcznie uszyte fartuchy z długimi rękawami, z wyłożonymi na nie białymi kołnierzykami; były dobrze utrzymane, bez chustek na głowie, z kunsztownie ułożonymi włosami, czyste i pachnące. [...] Wśród nich znajdowały się Żydówki, Polki i innej narodowości kobiety. [...] patrzyłyśmy na nie z zainteresowaniem, a zarazem z niechęcią, ponieważ wzbudziły w nas nieufność. Było bowiem godne zastanowienia, dlaczego jedne - tak straszliwie brudne, okryte łachmanami, przypominają upiory, a one - chociaż także więźniarki - są czyste, świeże, wyglądające zdrowo, i do tego mają włosy ${ }^{64}$.

Opowieści o włosach dokumentują też różnicę losu aryjek i Żydówek, których całe transporty golono po zagazowaniu. Paradoksalnie wstępne ogolenie było okolicznością pomyślną, bo oznaczało przyjęcie w skład więźniów obozu nieprzeznaczonych do bezpośredniej eksterminacji. Fragment zeznań Ewy Borger, Żydówki, byłej więźniarki obozu w Neusalz (Nowej Soli), osadzonej tam w roku 1944: „Rozpoczęły się kary za najmniejsze przewinienie. Za rozmowę z Polkami ścinano włosy lub postawiono na dwór na mrozie, bez płaszcza na 10-12 godz." ${ }^{\prime 65}$.

$\mathrm{Na}$,innej planecie” obozu zachowane zostało też fundamentalne kulturowe znaczenie włosów jako atrybutu kobiecej atrakcyjności o właściwościach erotycznych i seksualnych. To znów szeroki wątek problemowy, któremu tutaj nie poświęcę miejsca. Skalę takiego znaczenia włosów przecinało gdzieś poczucie człowieczeństwa, jako identyfikacji z ich posiadaniem, nawet w stanie fizycznego wyczerpania. Bo i „muzułmanki” starały się zakrywać łyse głowy. We Wspomnieniach oświęcimskich Antoniny Piątkowskiej przeczytamy:

Z tym [ogoleniem] nie mogły się pogodzić nie tylko nowo przybyłe, ale i te, które następnie stały się muzułmankami. Jakże często u muzułmanek, obojętnych już na wszystko, co się wokół działo, obserwować można było odruch zakrywania ogolonej głowy bodaj rękami, okręcania jej czym się dało. Płakały rozpaczliwie, nie mając czym okryć głowy, i uspokajały się natomiast, kiedy otrzymywały od którejś z więźniarek bodaj kawałek jakiejś szmatki ${ }^{66}$.

${ }^{64}$ I. Perkowska-Szczypiorska, dz. cyt., s. 90.

${ }^{65}$ Protokół zeznania przechowywany w Instytucie Źródłowym w Lund, opublikowany w: Mówiq świadkowie Ravensbrück. Wybór, wstęp i oprac. E.S. Kruszewski, Instytut Polsko-Skandynawski, Kopenhaga 2001, s. 7.

${ }^{66}$ A. Piątkowska, dz. cyt., s. 78-79. 
Odsłony innych znaczeń dokonują relacje obozowych fryzjerów i fryzjerek, zarówno tych frywolnie wspominających „klientki” stojące przed nimi na tabore$\operatorname{tach}^{67}$, jak i te obciążone największym dramatyzmem - wspomnienia fryzjerów z obozów zagłady. Trudno nie zacytować choć niewielkiego fragmentu literackiej narracji, który chociaż w sposób formalny doważyłby to skrajne doświadczenie.

Na podium świadków stoi czerwony z wysiłku Samuel Reisman. Trudno mu panować nad własnym wzruszeniem. Opowiada jak przebiegała praca w Himmelfahrstrasse w Treblince. [...] Zgodnie z planem wystarczało dziesięć minut na wykończenie wszystkich mężczyzn z transportu. Kobiety zajmowały więcej czasu, aż piętnaście minut, ponieważ przed wejściem do komory gazowej musiały być ostrzyżone... - Dlaczego? zapytał sędzia. - Ze względu na włosy, cenny surowiec do wyrobu materaców... ${ }^{68}$

Na koniec niewielki trybut na rzecz estetyki literackiego obrazu - w relacjach kobiet powracają przedstawienia z łysą głową ${ }^{69}$, czy wręcz pejzaże z łysymi głowami. Sięgnę do przykładu wysokiej artystycznej próby. Malarska wyobraźnia Charlotte Delbo przywołuje jakby kadry, powtarzalne plastyczne ujęcia z dominantą ogolonej głowy, która stanowi znaczące centrum obrazu.

Na początku wątpi się w to, co się widzi. Trzeba je odróżniać od śniegu. Wypełniają dziedziniec. Są nagie. Ułożone jeden przy drugim. Białe, niebieskawą bielą śniegu. Głowy są ogolone, włosy podbrzusza sterczą sztywno. Trupy są zmrożone, białe, paznokcie mają brązowe ${ }^{70}$.

Nagle na drogę wzdłuż drutów kolczastych wyjeżdża ciężarówka. Jedzie po śniegu bezgłośnie. Ciężarówka jest odkryta, służąca być może do przewożenia kamieni. Na niej znajdują się kobiety. Stoją. Mają nagie głowy, małe, ogolone, chłopięce głowy. Są ściśnięte, jedna przy drugiej. Ciężarówka jedzie w ciszy, głowy rysują się ostrymi konturami na błękicie dnia. Cicha ciężarówka sunie wzdłuż drutów jak duch. Na tle nieba fryz $\mathrm{z}$ twarzy ${ }^{71}$.

Łańcuch cytatów dotyczących obozowego doświadczenia kobiet związanego z włosami wydaje się nie mieć końca, taksonomię przypadków można rozwijać. „Sceny z włosami” stanowią w narracjach kobiecych granicę, poza którą znaj-

${ }^{67}$ J.M. Tired, Blok jedenasty, w: Kominy..., s. 208.

${ }^{68}$ S. Szmaglewska, Człowiek wolny przed międzynarodowym trybunatem, w: taż, Chleb i nadzieja, s. 185.

69 „To co przed sobą ujrzałam, było jakby obrazem piekła. Nie dlatego, że działo się tam [akurat] coś strasznego, ale dlatego, że pierwszy raz w moim życiu widziałam istoty, o których nie mogłam powiedzieć, czy to są mężczyźni czy kobiety. Głowy miały ogolone, były wychudzone, brudne i złamane swoim nieszczęściem”, W. Kiedrzyńska, dz. cyt., s. 97-98.

${ }^{70}$ C. Delbo, Żaden z nas nie powróci, s. 31.

${ }^{71}$ Tamże, s. 59 
duje się tabuizowane, drastyczne i tragiczne, obyczajowo nienormatywne, albo zarezerwowane dla obszaru poza narracją heroiczną, doświadczenie kobiet. Obozowych lesbijek, prostytutek puffów, więźniarek sprzedających seks za żywność i ubranie, żydowskich matek mordujących noworodki za szansę własnego przetrwania, ciężarnych spędzających płód za cenę pozostania w komandach pracy, kobiet pogwałconych obozowymi eksperymentami pseudomedycznymi i seksualnie zgwałconych, nie tylko przez obozowych oprawców, ale i wschodnich, i zachodnich wyzwolicieli. Wycinek sadystycznego obozowego piekła kobiet (od 1942 wskaźnik śmiertelności kobiet przewyższał śmiertelność mężczyzn ${ }^{72}$ oddają zapiski więźniów Sonderkommando.

Albo Scharführer Forst. Ten przy wielu transportach stawał w bramie rozbieralni i macał organ płciowy każdej młodej kobiety przechodzącej nago do komory gazowej. Zdarzały się także wypadki, gdy niemieccy SS-mani, wszelkich stopni, wtykali palec do organów płciowych młodych, ładnych dziewczą ${ }^{73}$.

$[\ldots]$ zhańbiono $[\ldots]$ nożami $[\ldots]$ nagim dziewczętom $[\ldots]$ w straszny sposób $[\ldots]$ wpychali im pałki w dolną część ciała [...] aż skonały w strasznych bólach i cierpieniach $[\ldots]$ starszych ludzi $[\ldots]$ sadyści wyciągali $[\ldots]$ zmuszali do gwałcenia $[\ldots]$ dzieci $[\ldots]$ również $[o n e ?][\ldots]$ zostały zabrane $[\ldots]$ a żony $\mathrm{z}$ ich rodzin $[\ldots]^{74}$.

Temat włosów jest fragmentem historii intymności kobiet w obozie, ale otwiera „zaledwie” jej czyściec.

\section{Bibliografia}

Amesberger Helga, Auer Katrin, Halbmayr Brigitte, Sexualisierte Gewalt. Weibliche Erfahrungen in NS-Konzentrationslagern, Mandelbaum, Wien 2004.

Archiwum Państwowe Muzeum Auchwitz-Birkenau, Zespół Oświadczenia, t. 75, k. 152.

Auerbach Rachela, Treblinka. Reportaż, oprac. Monika Polit, przeł. Karolina Szymaniak, „Zagłada Żydów. Studia i Materiały”, t. 8 (2012), s. 21-75.

Auschwitz 1940-1945. Węzłowe zagadnienia z dziejów obozu, red. Wacław Długoborski, Franciszek

Piper, Wydawnictwo Państwowego Muzeum Oświęcim-Brzezinka, Oświęcim, 1995, t. 2.

Banek Kazimierz, Opowieści o włosach. Zwyczaje, rytuały, symbolika, Trio, Warszawa 2010.

Birenbaum Halina, Nadzieja umiera ostatnia, Państwowe Muzeum Auschwitz-Birkenau, Oświę$\operatorname{cim} 2001$.

${ }^{72}$ N. Wachsmann, dz. cyt., s. 393.

${ }^{73}$ Nieznany autor (później zidentyfikowany jako Lejb Langfus ), Rękopis, w: Wśród koszmarnej zbrodni. Notatki więźniów Sonderkommando, wyd. 2 rozszerz., Wydawnictwo Państwowego Muzeum w Oświęcimiu, Oświęcim 1973, s. 172.

${ }^{74}$ Wydarzenia opisane $w$ dostępnym nam fragmentach najprawdopodobniej miały miejsce w obozie przejściowym w Małkini. Z. Lewental, Rękopis, w: Wśród koszmarnej zbrodni..., s. 194. 
Brzosko-Mędryk Danuta, Matylda, Wydawnictwo Ministerstwa Obrony Narodowej, Warszawa 1970.

Cebo Lechosław, Więźniarki w obozie hitlerowskim w Oświęcimiu-Brzezince, Wydawnictwo Uniwersytetu Śląskiego, Katowice 1984.

Ceran Sylwiusz Tomasz, Szmalcówka, Instytut Pamięci Narodowej, Bydgoszcz-Gdańsk 2010.

Czech Danuta, Kalendarz wydarzeń w KL Auschwitz, Wydawnictwo Państwowego Muzeum w Oświęcimiu-Brzezince, Oświęcim 1992.

Delbo Charlotte, Żaden z nas nie powróci, przeł. Katarzyna Malczewska-Giovanetti, Państwowe Muzeum Auschwitz-Birkenau, Oświęcim 2002.

Dokumenty zbrodni i męczeństwa, red. Michał Borwicz, Nella Rost, Józef Wulf, Centralny Komitet Żydów Polskich. Wojewódzka Żydowska Komisja Historyczna, Kraków 1945.

Dzieci żydowskie w czasach Zagłady. Wczesne świadectwa 1944-1948. Relacje dziecięce z Centralnej Żydowskiej Komisji Historycznej, oprac. Olga Orzeł, przekł. Eleonora Bergman, Piotr Kendziorek, Karolina Szymaniak, Żydowski Instytut Historyczny im. Emanuela Ringelbluma, Warszawa 2014.

Grzesiuk Stanisław, Pięć lat kacetu, Książka i Wiedza, Warszawa 1985.

Jaworska Janina, Nie wszystek umrę... Twórczość plastyczna Polaków w hitlerowskich więzieniach i obozach koncentracyjnych 1939-1945, Książka i Wiedza, Warszawa 1975.

Jezierska Maria Elżbieta, Pierwszy warszawski, w: Kominy. Oświęcim 1940-1945, przedm. Tadeusz Hołuj, Czytelnik, Warszawa 1962, s. 119-160.

Jurgielewiczowa Irena, Strategia czekania, Państwowy Instytut Wydawniczy, Warszawa 1982.

Kiedrzyńska Wanda, Ravensbrück - kobiecy obóz koncentracyjny, Książka i Wiedza, Warszawa 1961.

Laks Szymon, Gry oświęcimskie, Państwowe Muzeum Auschwitz-Birkenau, Oświęcim 1998.

Lanckorońska Karolina, Wspomnienia wojenne. 22 IX 1939 - 5 IV 1945, słowo wstępne Lech Kalinowski i Elżbieta Orman, Znak, Kraków 2001.

Levi Primo, Czy to jest człowiek?, przeł. Halszka Wiśniowska, Wydawnictwo Literackie, Kraków 1978.

Millu Liana, Dymy Birkenau, przeł. Krystyna i Eugeniusz Kabatcowie, Państwowe Muzeum Auschwitz-Birkenau, Oświęcim 2007.

Młodkowska-Bielawska Stanisława, Wspomnienia okupacyjne, oprac., wstępem i przypisami opatrzył oraz podał do dr. Robert Stopikowski, Wydawnictwo KUL, Lublin 2001.

Morawska Zofia, Warunki egzystencji więźniów, w: Majdanek 1941-1944, red. Tadeusz Mencel, Wydawnictwo Lubelskie, Lublin 1999, s. 129-169.

Mówia świadkowie Ravensbrück. Wybór, wstęp i oprac. Eugeniusz S. Kruszewski, Instytut Polsko-Skandynawski, Kopenhaga 2001.

Perkowska-Szczypiorska Irena, Kartki z Oświęcimia, w: Kominy. Oświęcim 1940-1945, przedm. Tadeusz Hołuj, Czytelnik, Warszawa 1962, s. 83-118.

Piątkowska Antonina, Wspomnienia oświęcimskie, przedm. Jan Masłowski, Wydawnictwo Literackie, Kraków 1977.

Piotrowski Michał, Nie tylko w Ravensbruck ...1723 dni za drutami KL Auschwitz, Neuengamme, Ravensbrück, Berlin-Lichterfelde, Prószyński i S-ka, Warszawa 1991.

Posmysz Zofia, Królestwo za mgła, Znak, Kraków 2017.

Posmysz Zofia, Ten sam doktor M, Iskry, Warszawa 1981.

Rutkowska-Kurcyuszowa Maria, Kamyki Dawida. Wspomnienia, Unia, Katowice 2005. 
Serca niezagasłe. Wspomnienia więżniarek z Ravensbruck, wybór Maria Kogut-Piotrowska i Andrzej Gierczak, oprac. Andrzej Gierczak, wstęp Jan Zaborowski, Wydawnictwo Ministerstwa Obrony Narodowej, Warszawa 1979.

Sofsky Wolfgang, Ustrój terroru. Obóz koncentracyjny, przekł. Małgorzata Łukasiewicz, Żydowski Instytut Historyczny im. Emanuela Ringelbluma, Warszawa 2016.

Springer Elisa, Milczenie żywych. W cieniu Auschwitz, opowieść o śmierci i zmartwychwstaniu, tłum. Krystyna i Eugeniusz Kabatcowie, Państwowe Muzeum Auschwitz-Birkenau, Oświęcim 2001.

Strzelecki Andrzej, Wykorzystanie zwłok ofiar obozu, „Zeszyty Oświęcimskie” 1995, nr 21, s. 87-141.

Szmaglewska Seweryna, Chleb i nadzieja, Wydawnictwo Ministerstwa Obrony Narodowej, Warszawa 1960.

Tired J.M., Blok jedenasty, w: Kominy. Oświęcim 1940-1945, przedm. Tadeusz Hołuj, Czytelnik, Warszawa 1962, s. 189-236.

Truszkowska-Kuliniczowa Anna, Mój XX wiek. Wspomnienia, Kampol, Szczecin 2004.

Wachsmann Nikolaus, Historia nazistowskich obozów koncentracyjnych, tłum. Maciej Antosiewicz, Świat Książki, Warszawa 2016.

Wśród koszmarnej zbrodni. Notatki więźniów Sonderkommando, wyd. 2 rozszerz., Wydawnictwo Państwowego Muzeum w Oświęcimiu, Oświęcim 1973.

Zawodna Marta, Wokót tego, co pozostało. Biograficzne podejście do badań nad szczatkami ludzkimi na przykładzie włosów eksponowanych w Muzeum Auschwitz-Birkenau, „Kultura i Społeczeństwo" 2007, nr 2, s. 65-90.

Zwyciężyly wartości. Wspomnienia z Ravensbrück, oprac. Urszula Wińska, Wydawnictwo Morskie, Gdańsk 1985.

\section{Barbara Czarnecka}

\section{Hair in Female Lager Narrations}

\section{(Summary)}

The article is the analysis of women's lager narrations that reflect the procedure of shaving hair applied to female lager prisoners. It shows cultural, social and psychological meanings of this procedure, presents it as the element of the wide scale lager violence strategy, degradation ritual, the form of female identity and intimacy violation. Through the presentation of various circumstances in which women were shaved in concentration camps the text presents the situation complexity of the lager experience - its phases and the context. The article relates the variety of sources and includes the experiences of women of different nationalities, for example: German, Polish, Jewish.

Keywords: female lager experiences; female lager narrations; hair; shaving; carnality; rape 